\title{
SPATIAL-TEMPORAL DISTRIBUTION OF CHLOROPHYLL-A IN SOUTHERN PART OF THE MAKASSAR STRAIT
}

\author{
Wasir Samad Daming ${ }^{1 *}$, Muhammad Anshar Amran ${ }^{1}$, Amir Hamzah Muhiddin ${ }^{1}$, Rahmadi Tambaru ${ }^{1}$
}

Submitted: 14 January 2018 Accepted: 19 February 2018

\begin{abstract}
Surface chlorophyll-a (Chl-a) distribution have been analyzed with seasonal variation during southeast monsoon in southern part of Makassar Strait and Flores Sea. Satellite data of Landsat-8 is applied to this study to formulate the distribution of chlorophyll concentration during monsoonal wind period. The distribution of chlorophyll concentration was normally peaked condition in August during southeast monsoon. Satellite data showed that a slowdown in the rise of the distribution of chlorophyll in September with a lower concentration than normal is likely due to a weakening the strength of southeast trade winds during June - July - August 2016. Further analysis shows that the southern part of the Makassar strait is likely occurrence of upwelling characterized by increase in surface chlorophyll concentrations were identified as the potential area of fishing ground.
\end{abstract}

Keywords: chlorophyll, Landsat-8, southeast monsoon, Makassar Strait

\section{INTRODUCTION}

The southern part of the Makassar Strait is one of the relatively more fertile waters because it is suspected that there is an increase in the mass of water in to the local and temporary surface layers in a narrow area. The fertile waters of the Makassar Strait occur throughout the year not only in the west season but also in the east seasons. In the western season, fertility occurs due to the run off of the mainland of Borneo and Sulawesi in large numbers due to high rainfall, while in the east season the fertility occurs due to the increase in water mass (upwelling) in the southern Makassar Strait. Nababan et al., (2009) revealed that high concentrations of chlorophyll-a surface are strongly suspected of upwelling in the eastern seasons until the start of the transition season (July-September) in the southern waters of the Makassar Strait indicated by cold temperatures and relatively high chlorophyll-a concentration. Kurniawati, et al., 2015 revealed that the distribution of chlorophyll- $a$ concentration in the ocean varies according to geographical location as well as depth of water. This variation is caused by the differences in the intensity of sunlight and the concentration of nutrients contained in the waters. Distribution of achlorophyll concentration is higher in coastal and coastal waters, as well as low chlorophyll-a concentration in offshore waters.

The rise of the inner layer water to the surface layers in the southern waters of the Makassar Strait was not only due to the circulatory impact of Indonesia's cross currents but the strong role of southeastern airflow (Samad, et al, 2015) and the influence of dipole modes from the Indian Ocean (Susanto et al., 2006 Curie et al., 2013). High water

${ }^{1}$ Department of Marine Science, Hasanuddin University Jl. Perintis Kemerdekaan Km. 10, Makassar 90245, Indonesia

*Wasir Samad Daming

Email: acilws@gmail.com productivity is identified by the high concentration of chlorophyll-a in these waters (Rashid, 2010). Chlorophyll-a concentration is one of the parameters that determine primary productivity at sea..

Spreading and high chlorophyll concentration is strongly associated with oceanic conditions Distribution of chlorophyll-a concentrations is generally high in coastal waters as a result of high nutrient supplies derived from land via river runoff, and low in offshore waters. However, high chlorophyll-a concentrations can also be found in offshore waters, due to the mass water circulation process (Sukoraharjo, 2012; Syahdan et al., 2014).

In addition, the exchange of water masses with the Pacific Ocean through the Sulawesi Sea, Flores Sea and Java Sea affects the primary productivity level in the southern waters of the Makassar Strait (Inaku, 2015, Kurniawati et al., 2015) to become one of the causes of the southern waters of the Makassar Strait to be highly dynamic which is closely related to the potential area of fisheries caused by the enrichment of nutrients in the area. This paper discusses the spatial dynamics of temporal distribution of chlorophyll-a southern waters of the Makassar Strait in relation to the potential location of fishing.

\section{MATERIAL AND METHOD}

The materials used in this research are Landsat-8 imagery covering the Southern waters of Makassar Strait on path / row 114/064 (downloaded from www.glovis.usgs.gov), Map of Indonesia, scale 1: 50.000, published by BAKOSURTANAL, as a reference in geometric correction, computer equipped with ENVI 5.1 image processing software.

This research was conducted at the beginning of the signal of east season period until the transition season (from east to west season) ie period from May to October 2016, covering data of chlorophyll$\mathrm{a}$ and sea surface temperature (SST). The 
chlorophyll and SST data are obtained from Landsat-8 imagery acquired on (a) May 21, 2016, (b) June 6, 2016, (c) June 22, 2016, (d) July 24, 2016, (e) August 9, 2016 (f) September 10, 2016, (g) September 26, 2016, (h) October 12, 2016.

\section{Chlorophyll-a}

Landsat-8 image processing for the distribution of chlorophyll-a using Ocean Color OC2 algorithm, i.e:

$$
\begin{gathered}
\log (\text { Chlorophyyll-a })=a_{0}+\sum a_{i} \log \left(R_{2} / R_{3}\right) i \\
m g / m^{3}
\end{gathered}
$$

Where :

$\mathrm{i}=1-4$.

$\mathrm{R}_{2}=$ reflectance of band -2 (blue)

$\mathrm{R}_{3}=$ reflectance of band -3 (green)

$\mathrm{a}_{0}, \mathrm{a}_{\mathrm{i}}=$ coeficient $\left(\mathrm{a}_{0}=0,1977 ; \mathrm{a}_{1}=-1,8117\right.$ $\left.a_{2}=1,9743 ; a_{3}=-2,5635 ; a_{4}=-0,7218\right)$.

\section{Sea Surface Temperature}

The thermal band data can be converted from spectral radiance to brightness temperature by using the thermal constants provided in image's metadata files (USGS, 2013):

$$
\mathrm{T}=\frac{\mathrm{K}_{2}}{\ln \left(\frac{\mathrm{K}_{1}}{\mathrm{~L}}+1\right)}-273
$$

Where:

$\mathrm{T}=$ brightness temperature $\left({ }^{\circ} \mathrm{C}\right)$

$\mathrm{L}=$ TOA spectral radiance (Watts $\left./\left(\mathrm{m}^{2} * \operatorname{srad} * \mu \mathrm{m}\right)\right)$

$\mathrm{K} 1=$ conversion constant for (K1_CONSTANT_BAND)

$\mathrm{K} 2$ = conversion constant for (K2_CONSTANT_BAND)

$\mathrm{K} 1$ and $\mathrm{K} 2$ listed in the image metadata file.

The above equation produces a T10 image. Converting pixel value to radiance value (TOA radiance) is done by using formula (USGS, 2013):

$$
\mathrm{L}_{\lambda}=\mathrm{M}_{\mathrm{L}} \mathrm{Q}_{\mathrm{cal}}+\mathrm{A}_{\mathrm{L}}
$$

Where:

$\mathrm{L}_{\lambda}=$ TOA spectral radiance $\left(\right.$ Watts $\left./\left(\mathrm{m}^{2} * \operatorname{srad}^{*} \mu \mathrm{m}\right)\right)$ pada band- $\lambda$

$\mathrm{ML}=$ multiplier factor of each band

(RADIANCE_MULT_BAND)

$\mathrm{AL}$ = additional factor of each band

(RADIANCE_ADD_BAND)

Qcal $=$ pixel digital values

ML and AL listed in the image metadata file. Sea surface temperature is obtained from the transformation:

$$
\mathrm{SST}=\left(5,971+1,859 \mathrm{~T}_{10}-0,035 \mathrm{~T}_{10}{ }^{2}\right)^{\circ} \mathrm{C}
$$

\section{RESULT AND DISCUSSION}

\section{East Wind Pattern}

The wind blowing in the east-season period is identified when entering April - October especially in the southern waters of the Makassar Strait. The wind that blows in the period of the east season is the result of the sun in the northern hemisphere, causing a difference of pressure between the continent of Asia and the continent of Australia, as the impact of the Australian continent faster cooling and high pressure compared to the warmer and lower-pressure Asia continent. In the period of east seasons, the southern waters of the Makassar Strait are influenced by east winds. This east wind is the southeast wind (east season) has a role to the formation of surface water circulation in the southern waters of the Makassar Strait. The pattern of east-east wind circulation over the waters of the Makassar Strait can affect the distribution of surface temperatures as they are with the circulation of wind-induced surface currents. The circulation of the inner water mass to the surface layer is the role of the southeast wind blowing force, the stronger the wind blow the greater the effect on the temperature distribution and the surface chlorophyll. The pattern of east wind circulation can be seen in Figure 1.

Based on wind data at the study site, in May the dominant wind direction comes from south to southeast to north to northwest with a speed of 1.0$4.0 \mathrm{~m} / \mathrm{s}$. In July-August wind direction is still dominant from southeast to east to west and northwest with speeds between $2-8 \mathrm{~m} / \mathrm{s}$. Then in Sep-Oct the wind direction is more dominant from east to west with speeds between 2-7 m / s. Although it has entered the transition season (transition) precisely wind direction is uncertain.

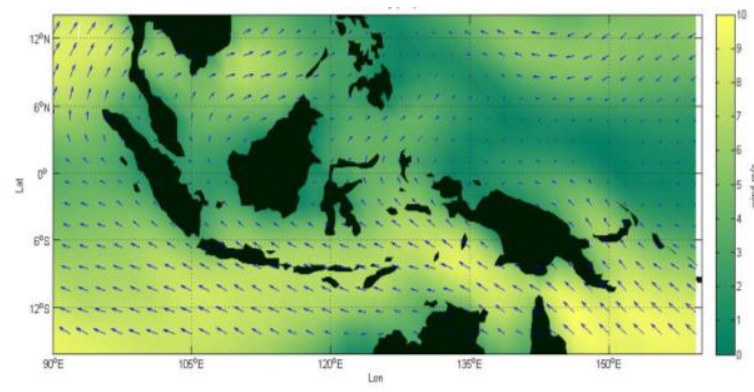

Figure 1. Profile of wind intensification during east season period (June-July-August)

\section{Distribution of Chlorophyll- $a$}

To investigate the evolution of 16-daily chlorophylla by using spatial and temporal analysis during the east-season period of Landsat- 8 imagery shows the presence of surface chlorophyll concentration fluctuations. Figure 2 shows the distribution of $16-$ daily chlorophyll-a concentrations in the southern waters of the Straits of Makassar that on May 21, June 22, August 9 and September 26 the surface chlorophyll concentrations showed higher values compared to chlorophyll-a concentrations on June 6 , July 24, September 10 and October 12 with an almost uniform distribution of concentration from the central waters to the southern part of the waters 
of South Sulawesi covering the southern waters of the Makassar Strait including the Java Sea and Flores Sea. Syahdan et al., (2014) revealed that the surface chlorophyll-a in the Makassar strait varies tends to increase toward the coast and vice versa decreases towards offshore. The high concentration of chlorophyll is one factor due to the high intensity of solar radiation that can cause blooming chlorophyll can form around the surface. This phenomenon is also reinforced by Rahardjo (2012) and Rashid (2010) which explains that oceanic oceanic conditions greatly affect the high-low concentration of chlorophyll on the surface. Distribution of this chlorophyll is generally concentrated more near sea level along the offshore of South Sulawesi from the west to the south of the coastal plains of South Sulawesi. It should be noted, however, that surface chlorophyll concentrations are inseparable from the dynamics of vertical water mass motions that tend to carry nutrients that can be identified as highly potential locations for pelagic fisheries. The fish response to fluctuations in chlorophyll-a which tends to be stable due to the nutrient availability required by phytoplankton is always available so that it impacts the chlorophyll-a concentration in the waters as shown in Figure 2. This condition will cause the fish to respond to other environmental factors suspected availability of stable chlorophyll-a, so it remains within tolerable limits, consequently small pelagic fish will tend to respond to fluctuations of other oceanographic factors, such as temperature, density and current. Different concentrations of chlorophyll-a each month in the southern waters of the Makassar Strait provide an indication that the presence of fish also fluctuates.

\section{Distribution of Sea Surface Temperature (SST)}

The variation of SST around the southern waters of the Makassar strait shows the 16-daily evolution of Landsat- 8 products. The SST distribution is processed based on the emergence of the eastern seasons signal up to the transition period (from the east to the west season) each periodic turn of the season. The monthly SST variation taken every 16 days during the period of the east season shows the fluctuation of sea surface temperature of the imaging results on May 21 and June 6 with values between $29.5^{\circ} \mathrm{C}-30.5^{\circ} \mathrm{C}$. However, the results of imaging at the time of intensive east winds blow show SST spreading in southern region of Makassar Strait is not evenly distributed, especially on July 24th. The result of the imaging shows the SST value reached in the temperature range between $28^{\circ} \mathrm{C}$ $30,5^{\circ} \mathrm{C}$ as shown in Figure 3.

The state of the sea surface temperature during May 2016 showed a uniform pattern of temperature spread. The temperature distribution in May 2016 from the daily 16 cycles shows the temperature
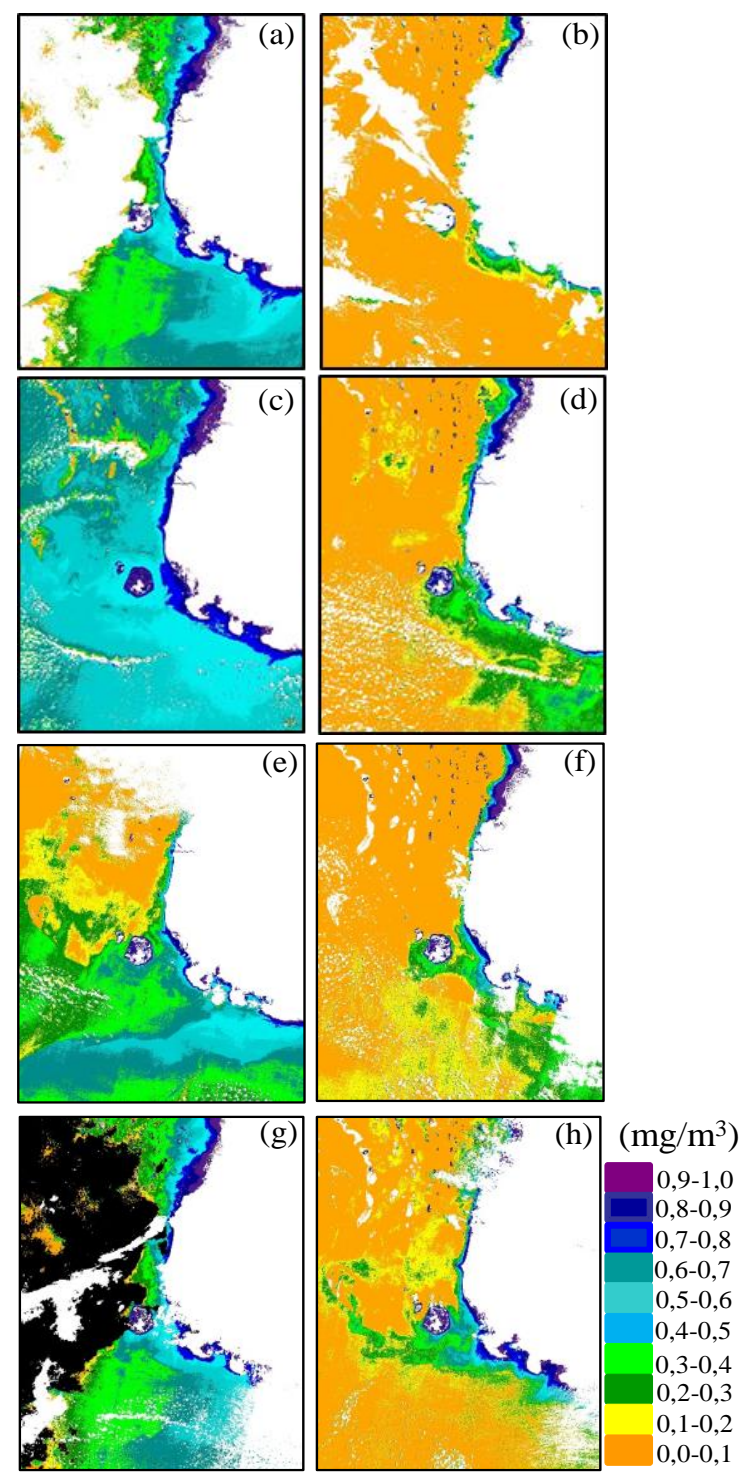

Figure 2. Map of Landsat- 8 satellite imagery of surface chlorophyll-a concentration $(\mathrm{mg} / \mathrm{m} 3)$ in east season 2016; (a) May 21, (b) June 6, (c) June 22, (d) July 24, (e) August 9, (f) Sept 10, (g) Sept 26, (h) October 12

range at $29.5^{\circ} \mathrm{C}-30.0^{\circ} \mathrm{C}$, which then increases in the first week of June (June 6, 2016) in the range $30.0{ }^{\circ} \mathrm{C}-30.5^{\circ} \mathrm{C}$. Entering the third week (June) again decreased in the range $29.0{ }^{\circ} \mathrm{C}-29.5{ }^{\circ} \mathrm{C}$. However, at the end of July the sea surface temperature significantly changed, in the southern part of mainland of South Sulawesi tends to decrease in the range $28.0{ }^{\circ} \mathrm{C}-28,5^{\circ} \mathrm{C}$ and this phenomenon has been strongly suspected the influence of southeast wind that has been very intensive blowing from the southeast. While in the north just in the range $30.0{ }^{\circ} \mathrm{C}-30.5{ }^{\circ} \mathrm{C}$. The presence of temperature fluctuations is possible by the influence of rivér inputs, and declining rainfall conditions

This phenomenon becomes interesting, because the results of imaging on July 24 showed a decrease of SST in southern of South Sulawesi did not increase 
chlorophyll concentration so that there was time lag between SST and chlorophyll-a. In contrast, Rasyid, (2010) revealed that increased chlorophyll concentrations are characterized along with decreasing sea surface temperatures. This phenomenon gives the assumption that the decrease of SST value is not necessarily followed by the increase of chlorophyll concentration. This study should be more comprehensive because it may be that the cause of the rise of the inner surface water mass to the surface is not the main cause of increased concentration of chlorophyll on the surface but there is a possibility of the influence of river runoff from the mainland, the internal sea due to the throughflow of Indonesia as well as the effect of eddy currents, so it needs a more in-depth study.

Sea surface temperatures when associated with estimation of fishing areas tend to fluctuate, in Rasyid, (2010) revealed that the tendency of small pelagic fish has the ability to adapt to the temperature range of measurement results ie $28{ }^{\circ} \mathrm{C}$ $30^{\circ} \mathrm{C}$. However, the optimum trend of catching is in the temperature range of $29 \mathrm{oC}-30 \mathrm{oC}$. Furthermore, it is said that fish have the ability to recognize and select a certain temperature range that provides the opportunity to perform activities to the maximum and ultimately affect the abundance and distribution. Upwelling and Catching Areas

The strength of the southeastern wind causes the mass transfer of the inner layer water to the surface. This displacement is followed by the motion of water particles that bring the life source to the ecosystem to grow and multiply.

Areas indicated by upwelling are closely related to the catchment area. Upwelling area is not only fertile but is a fish area for foraging. Rasyid, et al., (2010) explains that the presence of fish in tropical waters is related to monsoon variations of the marine environment. The influence of daytime long monsoon variations and the temperature of the tropical waters is not very influential when compared with equatorial regions. In the tropics wind and monsoon variations are more influential on marine ecosystems; where monsoon variations will affect the availability of quantities and types of food that directly affect the presence of fish in tropical marine ecosystems. In the southern part of Makassar Strait area identified upwelling occurs because during the period of east season in these waters have below normal surface temperatures ranging from $26{ }^{\circ} \mathrm{C}-28^{\circ} \mathrm{C}$ found in July September.

Figure 4 shows the monthly average of sea surface temperature and chlorophyll-a in the southern waters of the Makassar Strait, SST tends to decrease from June until October, while in May-October the chlorophyll concentration fluctuates. In July the concentration of chlorophyll increased but not

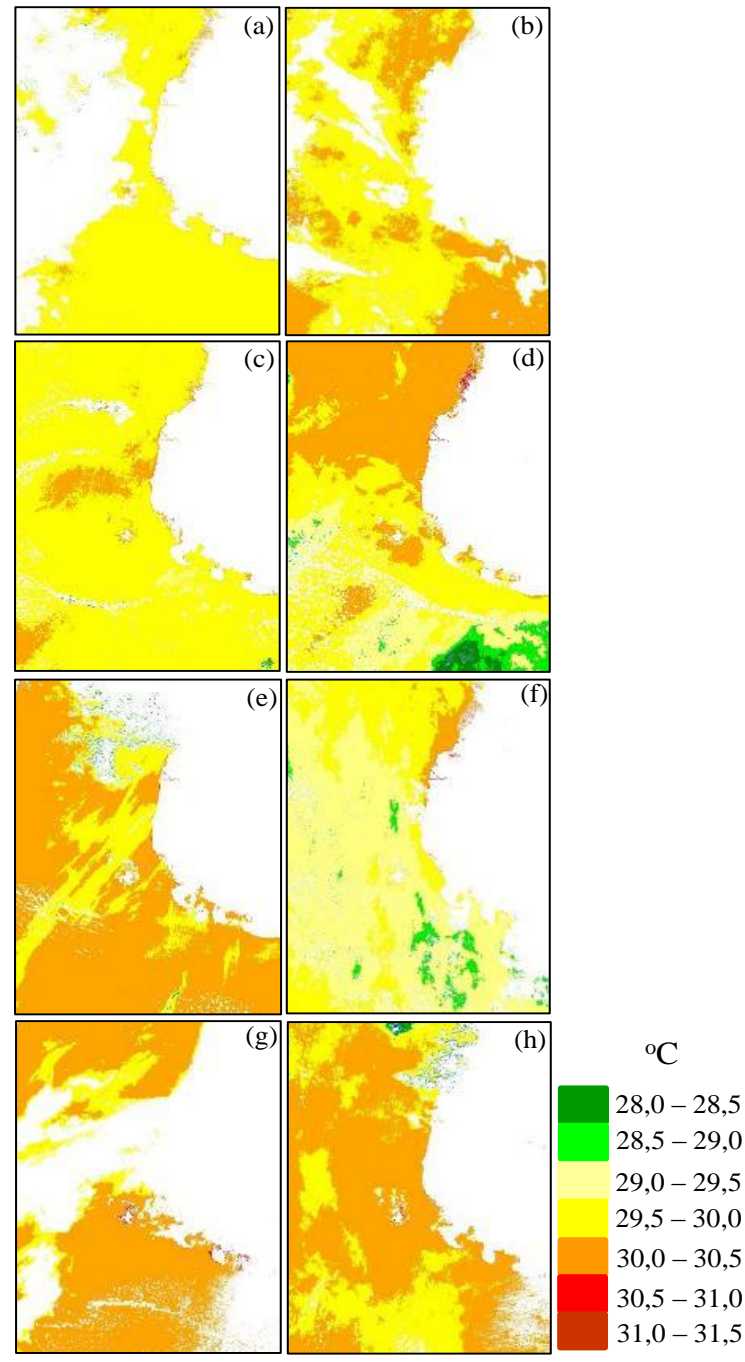

Figure 3. Landsat- 8 images of sea surface temperature $\left({ }^{\circ} \mathrm{C}\right)$ during the eastern seasons of 2016; (a) May 21, (b) June 6, (c) June 22, (d) July 24, (e) August 9, (f) Sept 10, (g) Sept 26, (h) Oct 12.

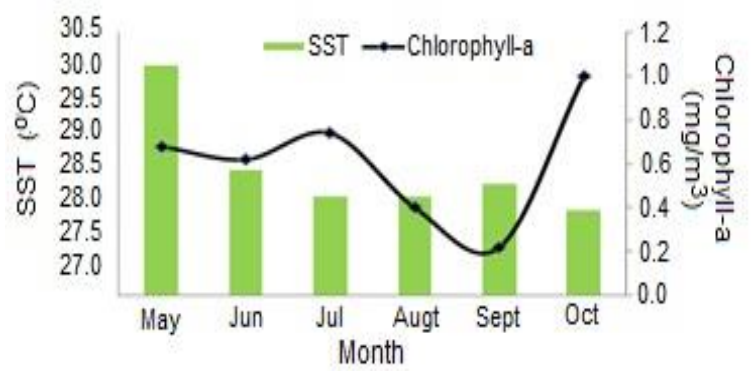

Figure 4. Graph between SST and Chlorophyll-a in the southern waters of Makassar Strait.

significant compared to the previous month, but in October it increased sharply to exceed $1 \mathrm{mg} / \mathrm{m}^{3}$. It is suspected that there is an impact of the massive increase of Makassar Strait water mass by the flow of Indonesian traffic. Strengthened by Sukoraharjo (2012) and Susanto, et.al. (2006) revealing that the role of Indonesia's cross-currents could trigger upwelling in the east season, so this area is highly potential for fish catching areas. 


\section{CONCLUSION}

Distribution of surface chlorophyll concentrations began to be detected by Landsat- 8 imagery at the time of the east season signal around the southern waters of the Makassar Strait. The high concentration of surface chlorophyll is not accompanied by decreasing sea surface temperature but there is a time lag. During the eastern seasons of 2016 there is upwelling in the southern waters of the Makassar Strait but is very weak and the period is short enough that marked the weakening of the southeast pasig wind, so it is not strong enough to push the water mass layer to the surface.

The variation of chlorophyll-a concentration content in the southern waters of the Makassar Strait is quite high in coastal areas and decreases in coastal waters offshore suspected to occur due to the influence of the flow of rivers from the mainland of South Sulawesi which empties into the waters of Makassar Strait.

\section{REFERENCES}

A. Rasyid J., "Distribusi suhu permukaan pada musim peralihan barat-timur terkait dengan fishing ground ikan pelagis kecil di perairan Spermonde", Jurnal Torani., vol. 20(1), pp. $1-7,2010$.

B. Nababan, D. Zulkarnain, J.L Gaol., "variabilitas konsentrasi klorofil-a di perairan utara sumbawa berdasarkan data satelit SeaWiFS", E-jurnal Ilmu dan Kelautan Kelautan Tropis", vol. 1 (2), pp. 72-83, 2009.

D. F. Inaku, "Analisis Pola Penyebaran dan Perkembangan Area Upwelling di Bagian Selatan Selat Makassar", Jurnal Torani vol. 25 (2) Agustus, pp.67-74, 2015.

F. Kurniawati, T.B Sanjoto, dan Juhadi, "Pendugaan Zona Potensi Penangkapan Ikan Pelagis
Kecil di Perairan Laut Jawa pada Musim Barat dan Musim Timur dengan Menggunakan Citra Aqua Modis," Geo Image 4 (2) 2015.

J. C. Currie, M. Lengaigne, J. Vialard, D. M. Kaplan, O. Aumont, S. W. A. Naqvi, and O.Maury, "Indian Ocean Dipole and El Niño/Southern Oscillation impacts on regional chlorophyll anomalies in the Indian Ocean", Ballast Water, vol. 6, no. 4, pp. 465-485, Aug. 2007.

M. Syahdan, A.S. Atmadipoera, S.B. Susilo, J.L Gaol, "Variability of surface Chlorophyll-a in the Makassar Strait-Java Sea, Indonesia", Intr.Journal of Sciences: Basic and Apllied Research (IJSBAR). Vol 14 no 2, pp. 103116. 2014.

S. S. Sukoraharjo," Variabilitas Konsentrasi Klorofil-a di Perairan Selat Makassar: Pendekatan Wavelet", Jurnal Sagara. Vol. 8(2) Desember, pp. 77-87, 2012.

R.D. Susanto, T. S. Moore II, and J. Marra," Ocean color variability in the Indonesian Seas during the SeaWiFS era", Geochemistry Geophysycs Geosystem, Vol.7, Q05021, 2006.

USGS, 2013, Using USGS Landsat-8 Product, diakses melalui http://landsat.usgs.gov.

USGS/EROS, 2012, Landsat Data Continuity Mission (LDCM) Lavel 1 (L1), Data Format Control Book (DFCB), diakses melalui http://landsat.usgs.gov

W.Samad, J-H Oh, D.A. Suriamihardja, D. Widyanuriyawan" Variasi Suhu Permukaan Laut dan Distribusi Klorofil di Perairan Indonesia", Prosiding Seminar Nasional Perikanan dan Kelautan $V$ Universitas Brawijaya. pp. 334-338, 2015. 